\title{
Influence of Digitalis on Time of Onset and Duration of Labour in Women with Cardiac Disease
}

\author{
JUDITH B. WEAVER, JAMES F. PEARSON
}

British Medical fournal, 1973, 3, 519-520

\section{Summary}

A comparison was made of the time of onset and duration of labour in 22 women taking digitalis and in 64 women who were not. Spontaneous labour occurred more than one week earlier and lasted about half as long in the patients taking digitalis. The likely explanation for this difierence is that digitalis has a direct action on the myometrium.

\section{Introduction}

It is now generally accepted that patients with cardiac disease do not have easy labours (Robertson, 1972), and there is no evidence that unselected patients with cardiac disease go into labour earlier or have shorter labours than the parturient population as a whole (McGarry and Pearson, 1973). It has, however, been shown that digitalis increases uterine muscle tone in vitro (Norris, 1961), and it has been suggested that the action of digitalis on the myometrium might affect the time of onset and duration of labour in patients with cardiac disease (Crawford, 1965). The present study was undertaken to investigate the influence of digitalis on the time of onset and duration of labour in patients with cardiac disease.

\section{Patients and Methods}

Eighty-six patients with cardiac disease were selected from the Cardiff Birth Survey (1965-9) according to the following criteria: (1) each patient was multiparous (primiparae were excluded because of the small numbers of digitalized patients included in the survey); (2) any patient whose pregnancy was complicated by any disorder other than cardiac disease was excluded; (3) the onset of labour was spontaneous and no oxytocin was administered at any time; (4) only singleton pregnancies with uncomplicated occipitoanterior presentations were included.

The control group consisted of 64 patients who did not receive digitalis, and the digitalis group consisted of 22 patients, all of whom were receiving digitalis by the 27th completed week of pregnancy.

Data were analysed with respect to maternal height and age, duration of pregnancy at the time of onset of labour, and the length of the first stage of labour; the onset was taken as regular uterine contractions every 5-10 minutes.

The outcome of pregnancy was assessed by comparing the birth weights of the infants and noting the percentile weight for gestation of each infant by the standards of Lubchenco et al. (1963) and Thomson et al. (1968). The one-minute total Apgar scores were also analysed.

Welsh National School of Medicine, University Hospital of Wales, Cardifi CF4 4XN

JUDITH B. WEAVER, M.B., M.R.C.o.G., Research Registrar, Department of Obstetrics and Gynaecology

JAMES F. PEARSON, M.D., M.R.C.o.G., Senior Lecturer and Consultant Obstetrician and Gynaecologist

\section{Results}

Maternal Data (table I).-No significant difference was found in the mean maternal height and age between the groups, showing that by physical standards the groups were similar. The duration of pregnancy at the spontaneous onset of labour for the patients in both groups is shown in fig. 1. Labour occurred more than one week earlier in the digitalis group than in the control group $(P<0.01)$. The mean duration of the first stage of labour in the digitalis group was $4 \frac{1}{\mathrm{~s}}$ hours (263 minutes), as opposed to about 8 hours (475 minutes) in the control group $(\mathbf{P}<0.001)$.

TABLE I-Control and Digitalis Groups compared with respect to Mean Maternal Age, Height, Length of Gestation at Onset of Labour and Duration of First Stage of Labout

\begin{tabular}{|c|c|c|c|c|c|c|c|}
\hline & \multicolumn{3}{|c|}{ Control Group } & \multicolumn{3}{|c|}{ Digitalis Group } & \multirow{2}{*}{$\begin{array}{c}\text { Significance } \\
\text { of Difference } \\
\text { ( } t \text { Test) }\end{array}$} \\
\hline & No. & Mean & S.E. & No. & Mean & S.E. & \\
\hline $\begin{array}{l}\text { Maternal age in years } \\
\text { Maternal height (in*) } \\
\text { Duration of pregnancy } \\
\text { at onset of labour } \\
\text { (weeks) } \\
\text { Duration of lst stage of } \\
\text { labour (min) }\end{array}$ & $\begin{array}{l}64 \\
63 \\
64 \\
64\end{array}$ & 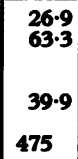 & $\begin{array}{c}0.6 \\
0.3 \\
0.2 \\
34\end{array}$ & $\begin{array}{l}22 \\
20 \\
22 \\
22\end{array}$ & \begin{tabular}{|c|}
$29 \cdot 3$ \\
$62 \cdot 7$ \\
\\
$38 \cdot 5$ \\
263
\end{tabular} & $\begin{array}{c}1 \cdot 2 \\
0.4 \\
0.4 \\
41\end{array}$ & $\begin{array}{c}\text { N.S. } \\
\text { N.S. } \\
P<0.01 \\
P<0.001\end{array}$ \\
\hline
\end{tabular}

$* 1$ in $=2.54 \mathrm{~cm}$.

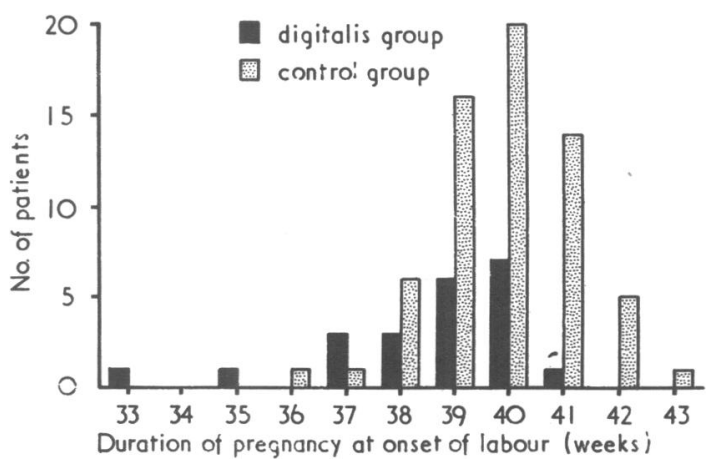

FIG. 1.-Duration of pregnancy (completed weeks) at onset of spontaneous labour.

Infant Data (table II).-The birth weights of the individual infants of the control and digitalis groups are shown in fig. 2, where they are related to gestational age corrected to the nearest completed week. The mean birth weight of the infants

TABLE II-Infants of Control and Digitalis Groups compared with respect to Mean Birth Weight, Percentile Weight for Gestation, and Apgar Score

\begin{tabular}{|c|c|c|c|c|c|c|c|}
\hline & \multicolumn{3}{|c|}{ Control Group } & \multicolumn{3}{|c|}{ Digitalis Group } & \multirow{2}{*}{$\begin{array}{l}\text { Significance } \\
\text { of Difference } \\
\text { ( } 2 \text { Teat) }\end{array}$} \\
\hline & No. & Mean & S.E. & No. & Mean & S.E. & \\
\hline $\begin{array}{l}\text { Birth weight (kg) } \\
\text { Percentile of birth } \\
\text { weight for gestation: } \\
\text { Lubchenco et al. } \\
\text { (1963) } \\
\text { Thomson et al. (1968) } \\
\text { Total Apgar score }\end{array}$ & $\begin{array}{l}64 \\
64 \\
64\end{array}$ & $\begin{array}{r}61 \cdot 6 \\
42.1 \\
8.8\end{array}$ & $\begin{array}{l}3 \cdot 1 \\
3.0 \\
0.1\end{array}$ & $\begin{array}{l}22 \\
22 \\
22\end{array}$ & $\begin{array}{r}54 \cdot 8 \\
32.6 \\
8.5\end{array}$ & $\begin{array}{l}5 \cdot 0 \\
4.8 \\
0.2\end{array}$ & $\begin{array}{l}\text { N.S. } \\
\text { N.S. } \\
\text { N.s. }\end{array}$ \\
\hline . & 64 & 8.8 & $0 \cdot 1$ & 22 & 8.5 & 0.2 & N.S. \\
\hline
\end{tabular}




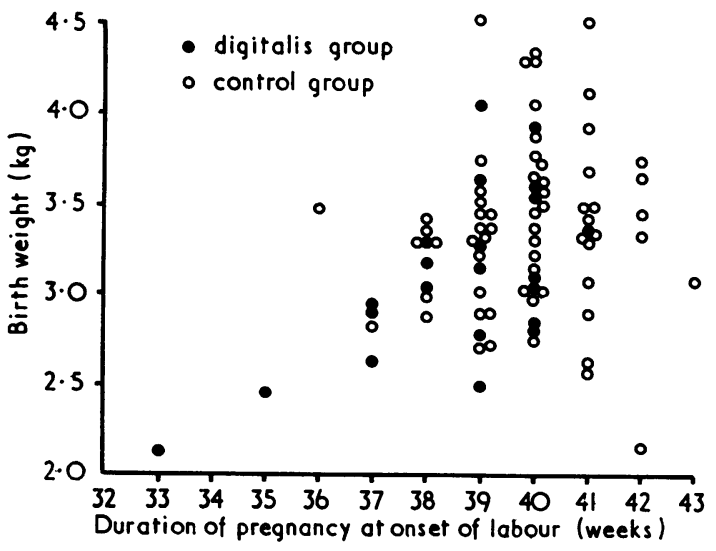

FIG. 2.-Birth weights of individual infants in both groups related to gestational age (completed weeks).

in the digitalis group was $300 \mathrm{~g}$ less than that of the infants in the control group ( $P<0.02$ using Student's $t$ test). The individual birth weights of infants in both groups were recalculated according to the criteria of Lubchenco et al. (1963), which takes into account differences in gestational age at birth and the sex of the infant, and also using the method recommended by Thomson et al. (1968), which includes, in addition to Lubchenco's criteria, correction factors for the differing maternal heights and weights. The percentile weights for gestational age of the infants were compared by means of $t$ tests and were similar in both groups of patients, suggesting that the difference in birth weight was purely reflective of the relative prematurity of the digitalis group and in no way indicated growth retardation. The total Apgar score at one minute was similar in both groups.

\section{Discussion}

Some similarity in response to cardiac glycosides of myocardium and myometrium was reported by Norris (1961), who showed increased tone and resistance to anoxia in digitalized myometrium in vitro. He was unable to show any effect on the time of onset of labour or duration of labour when digitalis in varying doses was given to primiparous patients for the last two weeks of pregnancy. He explained this observation by suggesting that digitalis decreases the efficiency of the normal heart and by analogy implied that digitalis could be expected only to increase the efficiency of a "failing" uterus. It has since been clearly shown, however, that digitalis increases the rate of intraventricular pressure development in patients without cardiac failure (Mason and Braunwald, 1963). We believe that the earlier onset and very much shorter labours in digitalized patients observed in this study might be consequent on the direct effect of digitalis on the myometrium exerted over a prolonged period.

We thank Professor A. C. Turnbull for his helpful advice and Dr. J. S. Crawford for posing the question.

\section{References}

Crawford, J. S. (1965). Principles and Practice of Obstetric Anaesthesia, p. 16. Oxford, Blackwell Scientific.

Lubchenco, L. O., Hansman, C., Dressler, M., and Boyd, E. (1963). Pediatrics, 32, 793.

McGarry, J., and Pearson, J. F. (1973). Lancet, 1, 483.

Mason, D. T., and Braunwald, E. (1963). Fournal of Clinical Investigation, 42, 1105 .

Norris, P. R. (1961). Fournal of Obstetrics and Gynaecology of the British Commonwealth, 68, 916 .

Robertson, J. D. (1972). In Integrated Obstetrics and Gynaecology for Postgraduates, ed. C. J. Dewhurst, p. 288. Oxford, Blackwell Scientific

Thomson, A. M., Billewicz, W. Z., and Hytten, F. E. (1968). Yournal of Obstetrics and Gynaecology of the British Commonwealth, 75, 903.

\title{
Serum Lipids in Cholelithiasis: Effect of Chenodeoxycholic Acid Therapy
}

\author{
G. D. BELL, B. LEWIS, A. PETRIE, R. HERMON DOWLING
}

British Medical fournal, 1973, 3, 520-522

\section{Summary}

Hypercholesterolaemia has been predicted as a possible complication of chenodeoxycholic acid treatment for gall stones. To exclude this, fasting serum lipids were measured in patients with stones before and at monthly intervals for six months after starting chenodeoxycholic acid. Before treatment half of a group of 36 patients with presumed cholesterol gall stones had serum cholesterol levels exceeding $260 \mathrm{mg} / 100 \mathrm{ml}$ or serum triglyceride values greater than $160 \mathrm{mg} / 100 \mathrm{ml}$ or both; these lipid levels were significantly greater than those in control subjects matched for age and sex. Treatment with chenodeoxycholic acid (0.5-1.5 g/day by mouth) did not change

Royal Postgraduate Medical School and Lipid Clinic, Hammersmith Hospital, London W12

G. D. BELL, M.SC., M.R.C.P., Research Fellow and Honorary Registrar B. LEWIS, M.D., M.R.C.PATH., Senior Lecturer in Chemical Pathology A. PETRIE, M.SC., Lecturer in Medical Statistics

R. HERMON DOWLING, M.D., M.R.C.P., Lecturer in Medicine and Consultant Physician serum cholesterol levels but did significantly reduce serum triglyceride concentrations from a pretreatment level of 118 ( \pm S.E. of mean 11.7) $\mathrm{mg} / 100 \mathrm{ml}$ to $95( \pm 7.2)$ $\mathrm{mg} / 100 \mathrm{ml}$ after six months of therapy. The mechanism of this triglyceride-lowering action of chenodeoxycholic acid is not known, but it may have therapeutic value in patients with hypertriglyceridaemia.

\section{Introduction}

Patients with cholesterol gall stones have a diminished bile acid pool (Vlahcevic et al., 1970) and a supersaturated bile in which there is insufficient bile acid and phospholipid to hold the cholesterol in solution (Admirand and Small, 1968). Treatment of such patients with the bile acid chenodeoxycholic acid repletes the bile acid pool (Danzinger, 1972), improves cholesterol solubility in bile (Thistle and Schoenfield, 1971), and promotes gall-stone dissolution (Bell et al., 1972; Danzinger et al., 1972). Against the benefits of gall-stone dissolution, however, must be set any complications of bile acid therapy, including the possible side effect of induced hypercholesterolaemia (Small, 1971). This was postulated because the major 